\title{
Pengaruh Penambahan Abu Batubara Terhadap Hasil Uji Kompaksi (Studi Kasus Tanah Lempung Toraja Utara)
}

\author{
Gerwin Kevin Bumbungan¹, John Patanduk², Irwan Lie Keng Wong*3 \\ *1 Mahasiswa Program Studi Teknik Sipil, Universitas Kristen Indonesia Paulus, Makassar, Indonesia \\ gerwinbumbungan@gmail.com \\ *2³ Dosen Program Studi Teknik Sipil, Universitas Kristen Indonesia Paulus, Makassar, Indonesia \\ patanduk.jhohanes@gmail.com dan irwanlie kw@yahoo.co.id
}

\begin{abstract}
ABSTRAK
Tanah merupakan dasar dari suatu struktur bangunan. Setiap daerah memiliki karakteristik dan sifat-sifat tanah yang bervariasi.Seringkali terdapat beberapa sifat tanah yang buruk dan kurang menguntungkan untuk suatu konstruksi bangunan.Contoh beberapa sifat tanah yang perlu diperhatikan adalah plastisitas yang tinggi, kekuatan geser yang rendah, kemampatan atau perubahan volume dan kembang susut yang besar. Sangat penting untuk mengetahui permasalahan tanah tersebut, serta memberikan upaya untuk memperbaikinya. Pengujian ini bertujuan untuk mengetahui penambahan abu batubara pada tanah,serta mengetahui nilai kadar air tanah dalam pengujian pemadatan tanah (kompaksi proctor) setelah dicampurkan abu batubara. Dari hasil pengujian pemadatan tanah diperoleh, tanah yang di stabilisasi dengan abu batubara pada variasi $0 \%, 10 \%, 15 \%, 20 \%$ dan $25 \%$ menunjukkan adanya peningkatan nilai kepadatan kering. Pada pengujian pemadatan tanah dengan pencampuran abu batubara nilai kepadatan kering dari variasi $0 \%$ sebesar 1,307 terus meningkat hingga $25 \%$ sebesar 1,379 .
\end{abstract}

Kata Kunci : abu batubara, tanah lempung, sifat fisik tanah, compaction standar proctor

\begin{abstract}
Soil is the basis of a building structure. Each area has varied soil characteristics and properties. Often there are some poor and less favorable soil properties for building construction. Examples of soil properties that need to be considered are high plasticity, low shear strength, compressibility, or changes in volume and swelling big shrinkage. It is very important to know the soil problem and make efforts to fix it. This test aims to determine the addition of fly ash to the soil, as well as to determine the value of soil moisture content in soil compaction testing (proctor compaction) after mixing fly ash. From the results of soil compaction testing, the soil stabilized with fly ash at variations of $0 \%, 10 \%, 15 \%, 20 \%$, and $25 \%$ indicates an increase in the value of dry density. In the soil compaction test by mixing fly ash, the dry density value of the variation of $0 \%$ was 1.307 and increased to $25 \%$ of 1.379
\end{abstract}

Keywords: fly ash, clay soil, soil physical properties, compaction standard proctor

\section{PENDAHULUAN}

Tanah didefinisikan sebagai material yang terdiri dari agregat (butiran) mineral - mineral padat yang tidak tersementasi (terikat secara kimia) satu sama lain dan dari bahan - bahan organik yang telah melapuk disertai dengan zat cair dan gas yang mengisi ruangruang kosong di antara partikel-partikel padat tersebut. Sifat tanah lempung yang plastis membuat tanah ini mengembang dan menyusut, permukaan air tanah meningkat tinggi pada waktu musim hujan dan tanah merekahpada waktu musim kemarau, sehingga apabila ada struktur atau infrastruktur bangunan diatas tanah tersebut, dapat dipastikan bangunan tersebut akan mengalami retak pada dindingnya atau mengalami penurunan, dan yang paling terjadi adalah keretakan plat lantai dan penurunan badan jalan. Demikian pula kasus yang terjadi di daerah Sa'dan Toraja Utara dimana kondisi badan jalan yang sudah mengalami keretakan hingga berlubang dan bergelombang. Maka dari studi kasus ini ingin dilakukan penelitian uji kompaksi dengan penambahan abu batubara untuk memperbaiki stabilitas tanah dan daya dukung tanah.

Tujuan penelitian untuk mengetahui karakteristik tanah asli dari Kecamatan Sa'dan Kabupaten Toraja Utara Provinsi Sulawesi Selatan dan menganalisis pengaruh penambahan Abu Batu Bara pada tanah lempung terhadap uji kompaksi (Compaction test). Variasi kadar Abu Batu Bara yang dicampurkan 
sebesar $0 \%, 5 \%, 10 \%, 15 \%, 20 \%$, dan $25 \%$ terhadap tanah kering total.

Penelitian sampel berada dilokasi Kecamatan Sa'dan Ballopasange' Kabupaten Toraja Utara, karena pada tempat pengambilan sampel terdapat jalan yang retak dan berlubang sehingga kami memutuskan untuk meneliti 2 titik pengambilan sampel pada jalan tersebut sebagai perbandingan. Dengan menggunakan transportasi umum sudah dapat sampai ke tempat pengambilan sampel. Setelah sampai, menggunakan alat sekop sampel tanah dimasukkan kedalam karung sebagai wadah sementara sebanyak $\pm 75 \mathrm{~kg}$ pada tiap titik yang diambil sebagai sampel penelitian. Setelah semuanya itu sampel tanah dibawa kembali ke laboratorium untuk dianalisis sifat tanah aslinya dan mengetahui pertambahan pemadatan pada saat abu batubara dicampur dengan tanah yang diuji. Total sampel pengujian untuk pemadatan (kompaksi) yaitu berjumlah 30 benda uji dari masing-masing titik penambahan abu batubara mulai dari $0 \%$ hingga 25 $\%$ berdasarkan dari berat tanah.

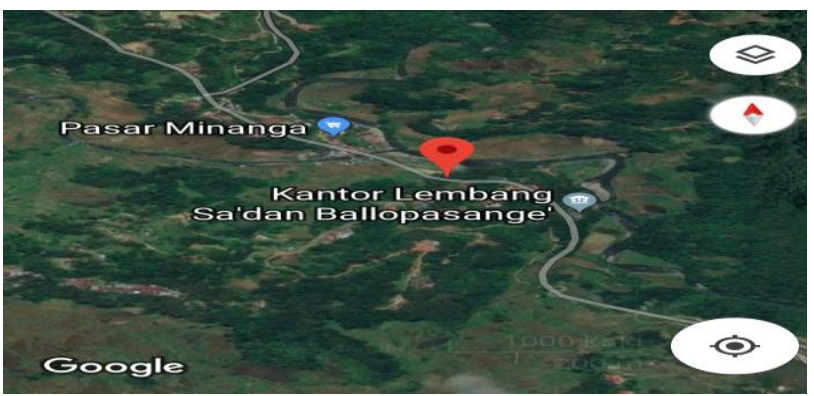

Gambar 1. Tempat pengambilan sampel

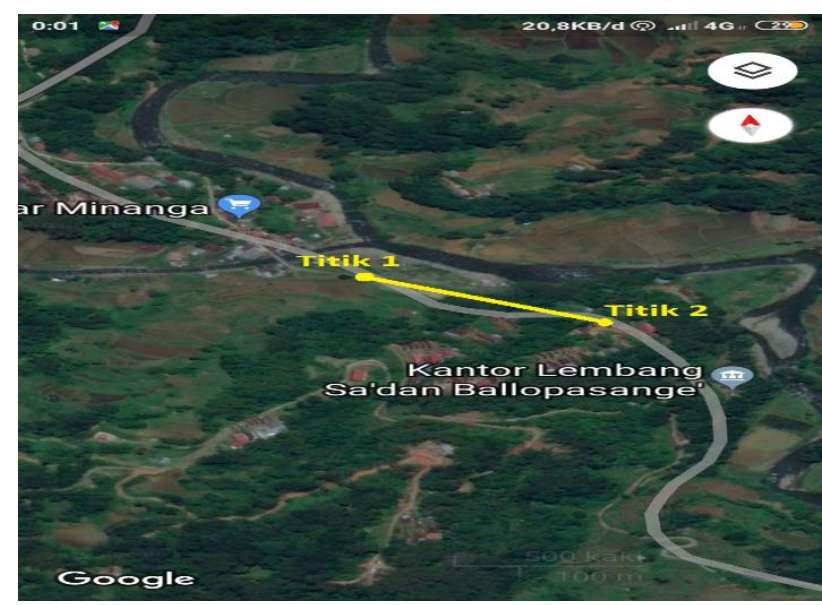

Gambar 2. Lokasi titik pengambilan sampel tanah di Sa'dan

Beberapa penelitian sejenis yaitu nilai tegangan geser tanah lempung dipengaruhi oleh jumlah abu batu bara [1], sifat fisis tanah dan mekanis landfill akan semakin baik dengan penambahan fly ash [2], campuran tanah fly ash serat dapat digunakan menjadi lapis penutup untuk tanah landfill [3], nilai batas plastis akan menurun seiring bertambahnya campuran semen dan fly ash, tetapi meningkatkan nilai batas cair dan indeks plastisitas [4], indeks plastisitas tanah lempung kuning akan berkurang akibat penambahan kapur [5], secara kualitatif, tanah gambut yang dipadatkan dengan proctor modifikasi memiliki parameter geser tanah dan kuat geser lebih baik dibandingkan dengan pemadatan tanah gambut dengan proctor standard[6], Larutan asam sulfat dapat meningkatkan nilai sifat mekanis dan fisis tanah, namun tidak berpengaruh secara signifikan terhadap swelling pressure dan potential [7].

\section{METODE}

Pengujian karakteristik tanah dilakukan sesuai dengan metode ASTM. Pengujian tersebut antara lain :

\section{Uji Kadar Air (ASTM D 2216)}

Pengujian kadar air tanah asli bertujuan untuk mendapatkan kadar air yang terdapat dilokasi. Sehingga dalam penelitian kadar air yang dilakukan di kecamatan sa'dan dilakukan sebanyak 3 sampel dari masing-masing titik.

\section{Uji Berat Jenis (ASTM D 854)}

Pengujian Berat Jenis tanah (Gs) yang akan diteliti di laboratorium dan dilakukan sebanyak dua sampel dari masing-masing tiap titik pengambilan sampel. Dari pengujian ini bertujuan untuk mendapatkan berat jenis tanah apa yang tergolong di kecamatan sa'dan tersebut.

\section{Uji Batas-batas Atterberg (ASTM 4318-95)}

Pengujian Batas-batas Atterberg yang akan dilakukan terbagi 3 yaitu batas plastis (plastic limit), batas cair (Liquid Limit) dan batas susut (Shrinkage Limit).

\section{Uji Analisis Butiran (ASTM D 422)}

Pengujian Analisis Butiran yang akan dilakukan terbagi 2 yaitu analisa saringan dan analisa hydrometer.

Dari uji karakteristik tanah diperoleh klasifikasi tanah yang digunakan sebagai sampel penelitian dan dilakukan uji pemadatan tanah dalam hal ini digunakan pemadatan proctor. Uji pemadatan proctor merupakan metode laboratorium untuk menentukan eksperimental kadar air yang optimal dimana suatu jenis tanah tertentu akan menjadi paling padat dan mencapai kepadatan kering maksimum.

Pengujian Kompaksi Proctor (ASTM-698) 
Pengujian Kompaksi dilakukan menggunakan sampel tanah asli yang dicampur dengan Abu batubara pada $0 \%, 5 \%, 10 \%, 15 \%, 20 \%$ dan $25 \%$ dari berat tanah kering lempung. Hasil pengujian ini berupa kadar air optimum/OMC (Optimum Moitre Content) dan berat volume kering maksimum untuk setiap variasi campuran.

\section{HASIL DAN PEMBAHASAN}

\section{Pengujian Sifat Fisis Tanah}

\section{Pengujian kadar air (ASTM D-2216)}

Pengujian kadar air tanah asli didapatkan nilai kadar air yang terkandung pada sampel 1 sebesar $22,3 \%$, dan sampel 2 sebesar $20,63 \%$.

\section{Pengujian berat jenis tanah (ASTM D854-58)}

Dari pengujian berat jenis tersebut didapatkan nilai berat jenis pada sampel 1 yaitu 2,61, dan sampel ke 2 yaitu 2,61. Angka ini menunjukkan tanah yang telah diteliti termasuk dalam golongan tanah lempung organik.
Pengujian batas - batas Atterberg (ASTM 4318-95)

Hasil pengujian batas-batas Atterberg pada sampel tanah asli yang telah diteliti di laboratorium mekanika tanah pada pengujian batas cair, batas plastis dan batas susut dapat dilihat pada Tabel 1 berikut ini :

Tabel 1. Pengujian batas-batas Atterberg tanah asli

\begin{tabular}{clll}
\hline & LL & PL & IP \\
\hline Tanah & 31,48 & 24,42 & 7,06 \\
Asli 1 & & & \\
\hline Tanah & 34,61 & 27,59 & 7,02 \\
Asli 2 & & & \\
\hline
\end{tabular}

Keterangan:

$$
\begin{array}{ll}
\mathrm{LL} & =\text { Batas Cair (\%) } \\
\mathrm{PL} & =\text { Batas Plastis (\%) } \\
\mathrm{IP} & =\text { Indeks Plastisitas (\%) }
\end{array}
$$

Menurut USCS, tanah termasuk berbutir halus pada titik 1 dan 2, karena titik 1 dan 2 persen lolos saringan 200 lebih dari $50 \%$. Nilai Indeks Plastisitas pada titik 1 dan 2 diperoleh $7 \%$ - 17\% yang berarti mempunyai sifat plastisitas sedang.

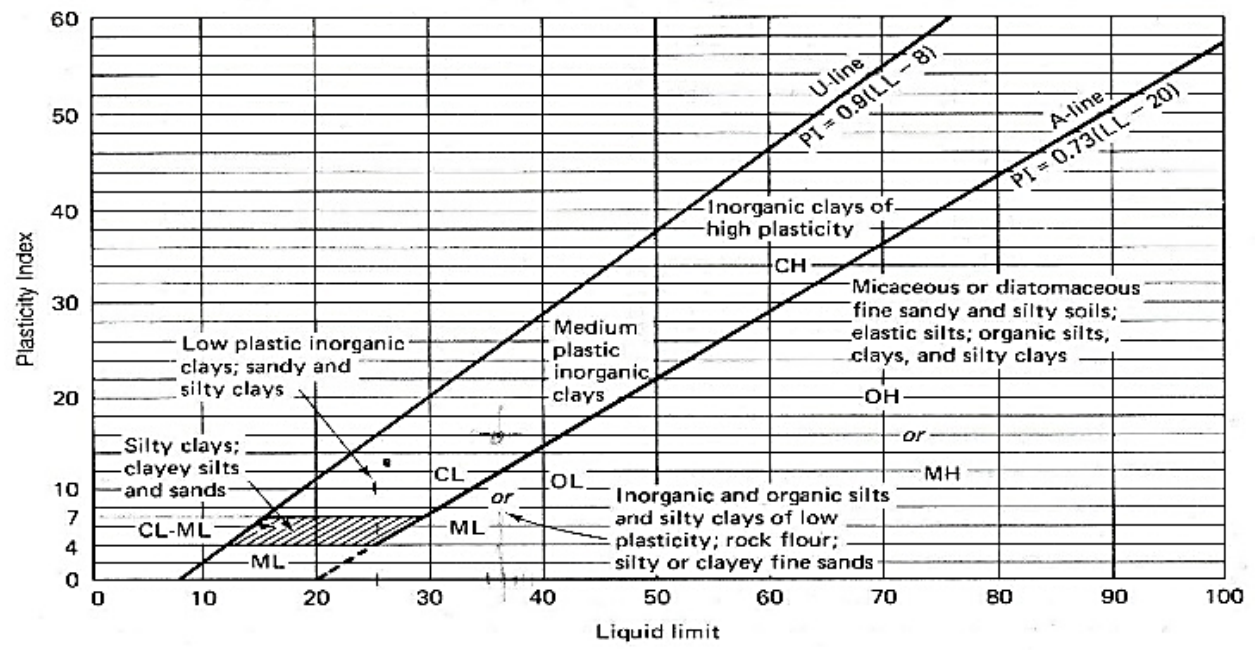

\section{Gambar 3. Plasticity chart}

Hubungan potensi pengembangan tanah lempung pada tiap titik dengan indeks plastisitasnya juga dapat diidentifikasi yaitu tanah mempunyai potensi pengembangan rendah karena nilai indeks plastisitas masuk pada interval $0-15 \%$ sehingga dapat diketahui potensi pengembangannya. Dari grafik plasticity chart diatas tanah yang diuji ini tergolong inorganic and organic silts and silty clays of low plasticity, rock flour, silty or clayey fine sands.

Pengujian Analisa Saringan (ASTM 422-63) dan Hydrometer (ASTM D1682-90)

Hasil pengujian yang diperoleh dari perhitungan analisa saringan yaitu nilai persen lolos tiap-tiap saringan yang kemudian dihubungkan dengan diameter saringan sehingga terbentuk sebuah garis yang menandakan bahwa sekian persen tanah berpasir yang diperoleh. Setelah itu, pada analisa hydrometer, diperoleh diameter butir dari pada tanah dan persentase kehalusannya. Kedua hal tersebut lalu dihubungkan pada titik koordinat tiap diameter saringan kemudian menghasilkan bahwa sekian persen tanah yang tergolong lanau dan lempung. Perolehan tanah berpasir, berlanau, dan berlempung bila dilihat dari grafik yaitu:

\footnotetext{
Sampel 1

Pasir : $100 \%-71,72 \%=28,28 \%$
}

Lanau : $71,72 \%-17,59 \%=54,13 \%$; dan

Lempung : $100 \%-(28,28 \%+54,13 \%)=17,59 \%$ 
Sampel 2

Pasir : $100 \%-88,26 \%=11,74 \%$

Lanau : $88,26 \%-15,12 \%=73,14 \%$; dan

\section{Pengujian Kompaksi Proctor}

Lempung : $100 \%-(11,74 \%+73,14 \%)=15,12 \%$

Tabel 2. Pengujian kompaksi proctor

\begin{tabular}{|l|c|c|c|c|c|}
\hline & $3 \mathrm{~kg}+550 \mathrm{ml}$ & $3 \mathrm{~kg}+600 \mathrm{ml}$ & $3 \mathrm{~kg}+650 \mathrm{ml}$ & $3 \mathrm{~kg}+700 \mathrm{ml}$ & $3 \mathrm{~kg}+750 \mathrm{ml}$ \\
\hline Berat Mold + Tanah basah & 6,250 & 6,300 & 6,350 & 6,370 & 6,410 \\
\hline Berat Mold & 4,900 & 4,900 & 4,900 & 4,900 & 4,900 \\
\hline Berat Tanah Basah & 1350 & 1400 & 1450 & 1470 & 1510 \\
\hline Volume Mold & 905.70 & 905.700 & 905.700 & 905.700 & 905.700 \\
\hline Berat Cawan + Tanah Basah & 18.17 & 17.29 & 22.92 & 23.54 & 25.80 \\
\hline Berat Cawan + Tanah Kering & 16.23 & 15.29 & 19.65 & 19.84 & 21.04 \\
\hline Berat Air & 1.94 & 2.00 & 3.27 & 3.70 & 4.76 \\
\hline Berat Cawan & 5.10 & 5.08 & 5.10 & 5.16 & 5.07 \\
\hline Berat Tanah Kering & 11.13 & 10.21 & 14.55 & 14.68 & 15.97 \\
\hline kadar air & 17.43 & 19.59 & 22.47 & 25.20 & 29.81 \\
\hline kepadatan & 1.49 & 1.55 & 1.60 & 1.62 & 1.67 \\
\hline kepadatan kering & 1.27 & 1.29 & 1.31 & 1.30 & 1.28 \\
\hline ZAV = Gs/1+((Gs+w)/80) & 1.71 & 1.66 & 1.60 & 1.54 & 1.48 \\
\hline
\end{tabular}

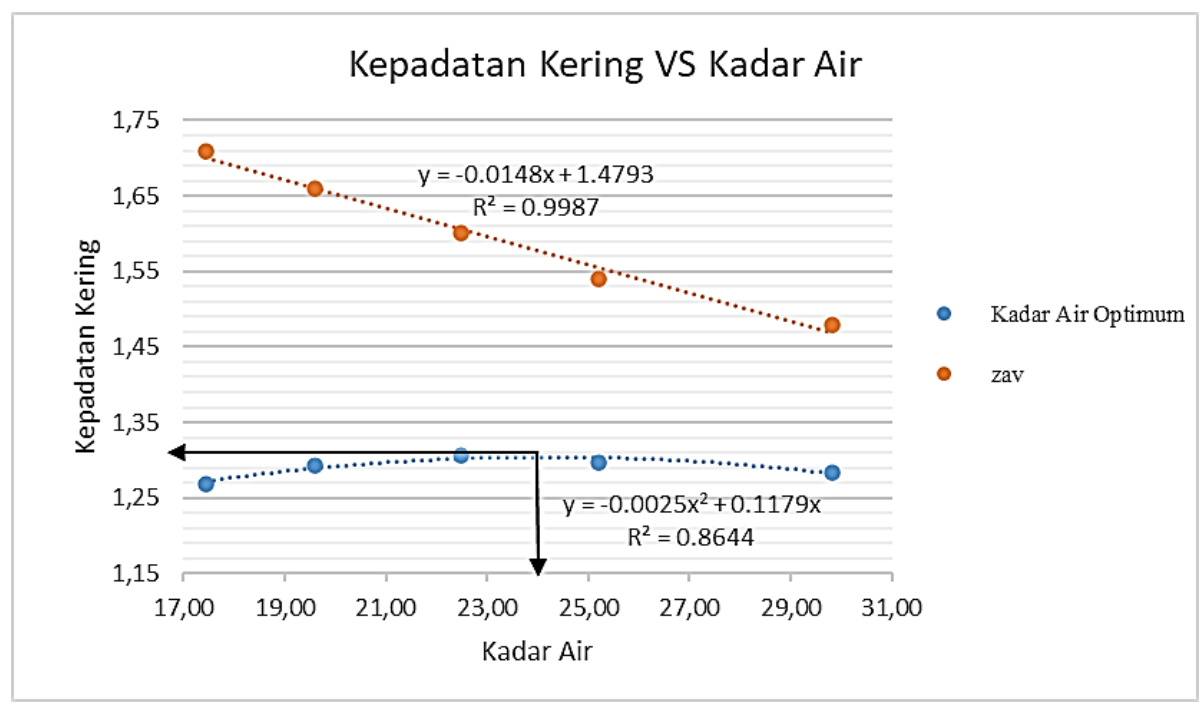

Gambar 4. Kompaksi proctor standard

Secara grafik, nilai kadar air optimum serta kepadatan kering, diperoleh dengan melihat dimana top dari parabola yang dihasilkan dari grafik hubungan kadar air dan kepadatan kering, lalu dapat ditarik garis lurus secara vertical serta horizontal dari top parabola tersebut, sehingga menghasilkan nilai untuk kadar air optimum sebesar 23,580 \% dan kepadatan kering $1,31 \mathrm{gr} / \mathrm{cm}^{3}$.

Sedangkan secara analisis, nilai untuk kadar air optimum dan kepadatan kering diperoleh dari persamaan linear yang dihasilkan dari grafik diatas, yaitu:
Untuk hubungan antara kadar air dengan ZAV (Zero Air Void), diperoleh persamaan: $\mathrm{y}=-0,0148 \mathrm{x}+$ 1,4793 . Yang bila diselesaikan:

$y=-0,0148 x+1,4793 ; y=0$, maka:

$0=-0,0148 x+1,4793$

$-1,4793=-0,0148 x$

$x=(-1,4793) /(-0,0148)$

$x=99,95$

Sedangkan maksud dari ZAV 100\% menunjukkan bahwa kondisi pori-pori tanah sudah tidak mengandung udara lagi. Diperoleh hasil dari persamaan diatas adalah $99,95 \%$ atau dapat dianggap $100 \%$ udara dalam pori sudah tidak ada 
lagi.Untuk hubungan antara kadar air dengan kepadatan kering, diperoleh persamaan : $y=-0,0025$ $x^{2}+0,1179 x$. Bila diselesaikan :

$y=-0,0025 x^{2}+0,1179 x ; y=0$, maka :

$0=-0,0025 x^{2}+0,1179 x$

$0,0050 x=0,1179$

$\mathrm{x}=(0,1179) /(0,0050)$ $x=23,580$; setelah diperoleh nilai $x$, maka :

$y=-0,0025 x^{2}+0,1179 x$

$y=\left(-0,0025\left(23,580^{2}\right)\right)+(0,1179(23,580))$

$y=(-1,330)+2.660$

$y=1,31$

Tabel 2. Hasil perhitungan pemadatan sampel 2

\begin{tabular}{|l|c|c|c|c|c|}
\hline & $3 \mathrm{~kg}+550 \mathrm{ml}$ & $3 \mathrm{~kg}+600 \mathrm{ml}$ & $3 \mathrm{~kg}+650 \mathrm{ml}$ & $3 \mathrm{~kg}+700 \mathrm{ml}$ & $3 \mathrm{~kg}+750 \mathrm{ml}$ \\
\hline Berat Mold + Tanah basah & 6,250 & 6,310 & 6,360 & 6,370 & 6,400 \\
\hline Berat Mold & 4,900 & 4,900 & 4,900 & 4,900 & 4,900 \\
\hline Berat Tanah Basah & 1350 & 1410 & 1460 & 1470 & 1500 \\
\hline Volume Mold & 905.70 & 905.70 & 905.70 & 905.70 & 905.70 \\
\hline Berat Cawan + Tanah Basah & 15.76 & 14.53 & 14.91 & 17.66 & 20.17 \\
\hline Berat Cawan + Tanah Kering & 14.15 & 12.88 & 13.01 & 15.02 & 16.70 \\
\hline Berat Air & 1.61 & 1.65 & 1.90 & 2.64 & 3.47 \\
\hline Berat Cawan & 4.97 & 5.12 & 5.09 & 5.10 & 5.07 \\
\hline Berat Tanah Kering & 9.18 & 7.76 & 7.92 & 9.92 & 11.63 \\
\hline kadar air & 17.538 & 21.263 & 23.990 & 26.613 & 29.837 \\
\hline kepadatan & 1.491 & 1.557 & 1.612 & 1.623 & 1.656 \\
\hline kepadatan kering & 1.268 & 1.284 & 1.300 & 1.282 & 1.276 \\
\hline ZAV=Gs/1+((Gs+w)/80) & 1.690 & 1.650 & 1.610 & 1.570 & 1.540 \\
\hline
\end{tabular}

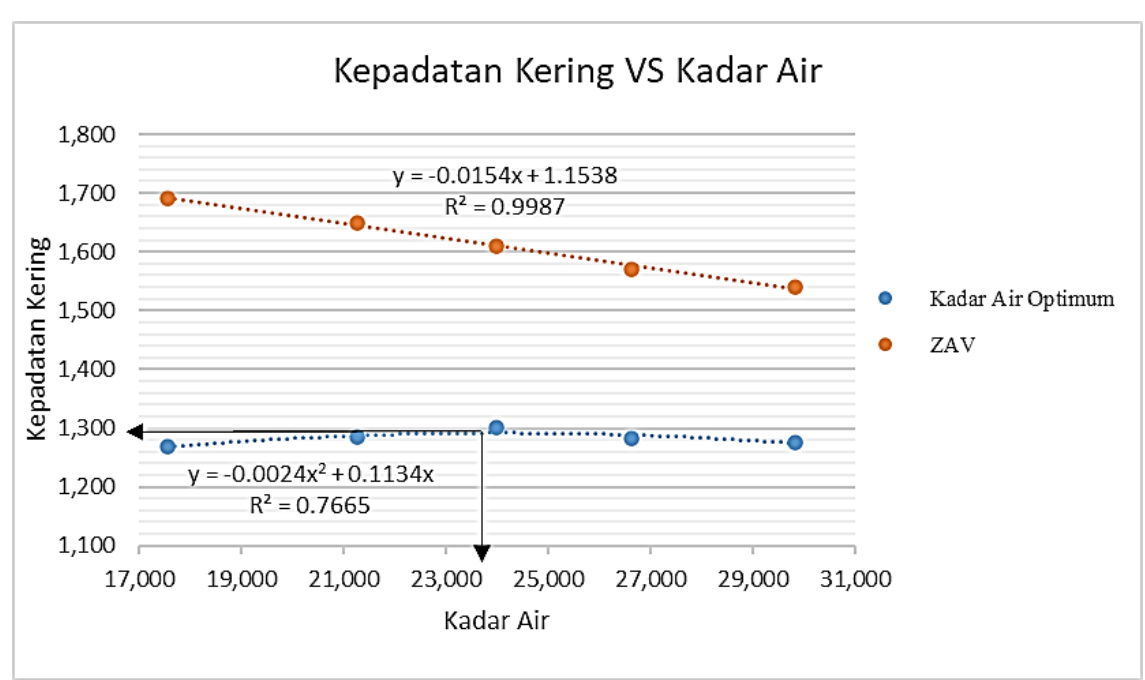

Gambar 5. Kompaksi proctor standard

Secara grafik, nilai kadar air optimum serta kepadatan kering, diperoleh dengan melihat dimana top dari parabola yang dihasilkan dari grafik hubungan kadar air dan kepadatan kering, lalu dapat ditarik garis lurus secara vertical serta horizontal dari top parabola tersebut, sehingga menghasilkan nilai untuk kadar air optimum sebesar 23,625 \% dan kepadatan kering $1,300 \mathrm{gr} / \mathrm{cm}^{3}$.
Sedangkan secara analisis, nilai untuk kadar air optimum dan kepadatan kering diperoleh dari persamaan linear yang dihasilkan dari grafik diatas, yaitu:

Untuk hubungan antara kadar air dengan ZAV (Zero Air Void), diperoleh persamaan : $\mathrm{y}=-0,0154 \mathrm{x}+$ 1,5388 . Yang bila diselesaikan $y=-0,0154 x+1,5388 \quad ; y=0$, maka :
$0=-0,0154 x+1,5388$ 


$$
\begin{aligned}
& -1,5388=-0,0154 x \\
& x=(-1,5388) /(-0,0154) \\
& x=99,92
\end{aligned}
$$

Sedangkan maksud dari ZAV $100 \%$ menunjukkan bahwa kondisi pori-pori tanah sudah tidak mengandung udara lagi. Diperoleh hasil dari persamaan diatas adalah $99,92 \%$ atau dapat dianggap $100 \%$ udara dalam pori sudah tidak ada lagi.

Untuk hubungan antara kadar air dengan kepadatan kering, diperoleh persamaan : $y=-0,0024 x^{2}+$ $0,1134 \times$. Bila diselesaikan :

$y=-0,0024 x^{2}+0,1134 x ; y=0$, maka :

$0=-0,0024 x^{2}+0,1134 x$

$0,0048 x=0,1134$

$\mathrm{x}=(0,1134) /(0,0048)$

$x=23,625$; setelah diperoleh nilai $x$, maka :

$y=-0,0024 x^{2}+0,1134 x$

$y=\left(-0,0024\left(23,625^{2}\right)\right)+(0,1134(23,625))$

$y=(-1,294)+2,588$

$y=1,300$

\section{Pengujian Kompaksi Dalam Penambahan Abu Batubara}

Tabel 3. Hasil pengujian pemadatan tanah

\begin{tabular}{ccc}
\hline \multirow{2}{*}{$\begin{array}{c}\text { Campuran Abu } \\
\text { Batubara }\end{array}$} & \multicolumn{2}{c}{ Kepadatan Kering } \\
\cline { 2 - 3 } & Sampel 1 & Sampel 2 \\
\hline $0 \%$ & 1.307 & 1.300 \\
\hline $5 \%$ & 1.340 & 1.306 \\
\hline $10 \%$ & 1.346 & 1.309 \\
\hline $15 \%$ & 1.361 & 1.325 \\
\hline $20 \%$ & 1.370 & 1.330 \\
\hline $25 \%$ & 1.379 & 1.336 \\
\hline
\end{tabular}

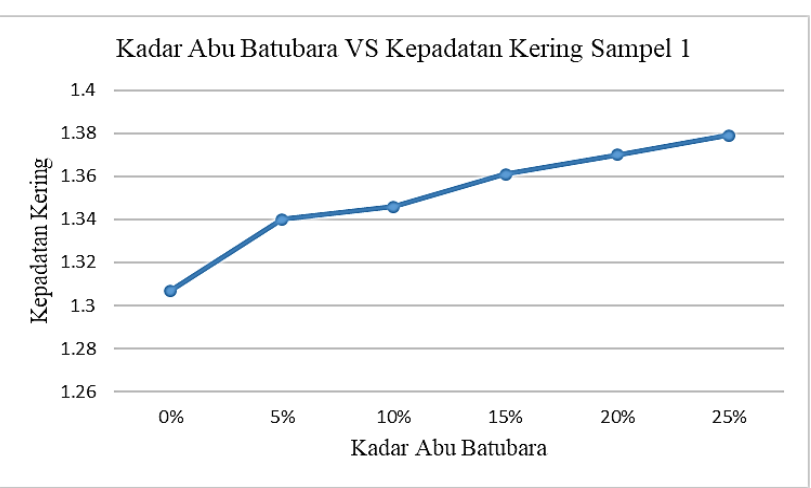

Gambar 6. Kadar abu batubara terhadap kepadatan kering sampel 1

Pada sampel 1 pencampuran tanah dengan abu batubara menunjukkan nilai kepadatan kering berbanding lurus dengan persen abu batubara dari $0 \%$ sampai $25 \%$ mengalami peningkatan. Hal ini berarti tanah pada sampel 1 cocok saat ditambahkan abu batubara dengan prosentase $5 \%$ hingga $25 \%$.

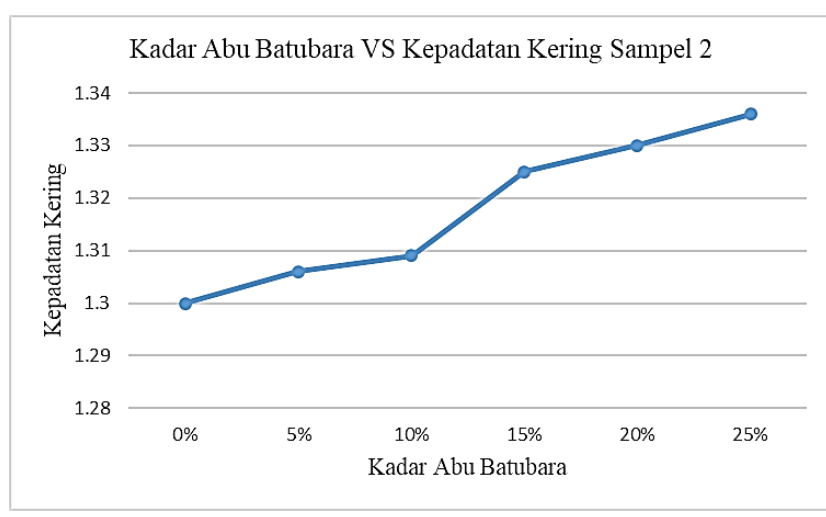

Gambar 7. Grafik abu batubara terhadap wopt (\%)

Pada sampel 2 pencampuran tanah dengan abu batubara menunjukkan nilai kepadatan kering berbanding lurus dengan persen abu batubara dari $0 \%$ sampai $25 \%$ mengalami peningkatan. Hal ini berarti tanah pada sampel 2 juga cocok saat ditambahkan abu batubara dengan prosentase 5\% hingga 25\%.

\section{Pembahasan}

\section{Pengujian Sifat fisis Tanah}

Rekapitulasi hasil pengujian sifat fisis tanah Kecamatan Sa'dan, diperoleh Hasil Pengujian Kadar Air dengan rata-rata 22,3\%, Pengujian Berat Jenis dengan rata-rata $2,61 \mathrm{gr} / \mathrm{cm}^{3}$ angka ini menunjukan bahwa tanah ini termasuk tanah lempung organik, Pengujian Batas-batas Atterberg yang terdiri dari Batas Plastis yaitu $24,42 \%$, Batas Cair yaitu $31,48 \%$, dan Indeks Plastisitas yaitu 7,06 yang berarti mempunyai sifat plastisitas rendah kohesif. Dan Pengujian Gradasi Analisa Saringan dan Hydrometer, dimana persen lolos saringan no.200 sebesar $71,72 \%$, serta pengujian hydrometer mendapatkan hasil bahwa sampel tanah yang tergolong pasir sebesar $28,28 \%$, lanau sebesar $54,13 \%$ dan lempung $17,59 \%$.

\section{Pengujian Kompaksi Proctor dalam Penambahan Abu Batubara}

Hasil pengujian dari kompaksi proctor dengan penambahan abu batubara, Persentase Abu batubara dan Kepadatan Kering pada sampel 1 mengalami peningkatan, dimana pengujian kadar air optimum dari $0 \%$ sebesar 1,307 terus meningkat pada penambahan kadar abu batubara hingga $25 \%$ sebesar 1,379. Pada sampel 2 juga mengalami peningkatan, dimana pengujian kadar air optimum dari $0 \%$ sebesar 1,300 terus meningkat pada penambahan kadar abu batubara hingga $25 \%$ sebesar 1,336 . 
Dari pengujian ini menunjukan bahwa dari masingmasing sampel tanah dengan campuran abu batubara dapat meningkatkan kadar air optimum dari setiap sampel karena abu batubara memiliki kemampuan untuk mengikat dan menyimpan air sehingga tanah yang tercampur abu batubara menjadi padat dan stabil.

\section{KESIMPULAN}

Sampel tanah dari Lembang Sa'dan, Toraja Utara merupakan tanah lempung organik karena mendapatkan hasil nilai berat jenis $2,61 \mathrm{gr} / \mathrm{cm}^{3}$

\section{DAFTAR PUSTAKA}

[1] Sindy.P, O.B.A.Sompie, dan Lanny D.K.M., 2018, "Pengaruh Penambahan Abu Batu Bara Terhadap Kuat Geser Tanah Lempung", Jurnal Tekno Vol.16, no.69.

[2] Agus.T., 2012, "Stabilisasi Landfill dengan Fly Ash", Jurnal Widya Teknika, Vol.20, no.2.

[3] Sukirman N, 2016, "Kinerja Tanah Lunak Stabilisasi Fly Ash Dengan Perkuatan Serat Alami Sebagai Lapis Penutup Landfill" Disertasi, Teknik Sipil, Universitas Hasanuddin

[4] Husnah, 2019, "Stabilisasi Tanah Lempung Menggunakan Semen dan Fly Ash" Rab Construction Research, Vol.4, no.1. dengan kadar air tanah asli sebesar $22,3 \%$, serta nilai Indeks Plastisitas $7,06 \%$ dengan sifat plastisitas tergolong sedang dari interval $7 \%-17 \%$.

Dari pengujian Pemadatan Tanah (Kompaksi Proctor) dengan penambahan Abu batubara dari kedua sampel terjadi peningkatan kepadatan kering pada sampel 1 mulai $0 \%$ sebesar 1,307 hingga 25\% sebesar 1,379 sedangkan kepadatan kering pada sampel 2 mulai $0 \%$ sebesar 1,300 hingga $25 \%$ sebesar 1,336 dari tanah lempung normal, hal ini juga tidak menutupi kemungkinan akan terus meningkat pada kadar abu batubara yang lebih besar lagi.

[5] T. J. Syamdiofa, M. Munirwansyah, dan R. Anggraini, 2018, "Pengaruh Kapur Sebagai Stabilizing Agent Terhadap Indeks Plastisitas dan Kuat Geser Lempung Ekspansif Meunasah Rayeuk", Jurnal Arsip Rekayasa Sipil Dan Perencanaan., Vol. 1, no. 4, doi: 10.24815/jarsp.v1i4.12460.

[6] C. Irawan,2010, "Pengaruh Pemadatan Dengan Proctor Modifikasi Pada Kuat Geser Tanah Gambut Melalui Uji Triaksial Consolidated Undrained", Skripsi Teknik Sipil Universitas Indonesia.

[7] S. Prabandiyani RW, S. Hardiyati, M. Muhrozi, dan B. Pardoyo, 2015, "Stabilisasi Tanah Lempung dengan Mengunakan Larutan Asam Sulfat (H2so4) pada Tanah Dasar di Daerah Godong - Purwodadi Km 50 Kabupaten Grogogan," MEDIA Komun. Tek. SIPIL, Vol. 21, no. 1, doi: $10.14710 / \mathrm{mkts} . v 21 \mathrm{i} 1.11227$. 